\title{
Schedule of technical meeting
}

研究調査運営委員会情報

\section{• 2019 年 3 月 2019 年 9 月 研究会計画：テーマと開催地一覧}

2018 年 12 月時点の計画を掲載しています。最新情報は各技術委員会ホームページを参照ください。また, 研究 会の詳細については電気学会ホームページ（http://www.iee.jp/?page_id=6818）を参照ください。

\begin{tabular}{|c|c|c|c|c|}
\hline $\begin{array}{l}\text { 技術委員会/委員長 } \\
\text { ホームベージアドレス }\end{array}$ & 研究会テーマ & 開催地 & 開催月 & 共催·連催•併催 \\
\hline \multirow{3}{*}{$\begin{array}{l}\text { 半導体電力変換 }(\mathrm{SPC}) \\
\text { 船渡 寛人 (宇都宮大学) } \\
\text { http://www2.iee.or.jp/ dspc/ }\end{array}$} & $\begin{array}{l}\text { 電力技術に適用される半導体電力変換技及び半導体電力変換 } \\
\text { 一般 }\end{array}$ & 沖縄 & 3 月 & $\begin{array}{c}\text { B部門 電力技術委員会·電力 } \\
\text { 系統技術委員会 }\end{array}$ \\
\hline & エネルギー技術及び半導体電力変換技術一般 & 未定 & 7 月 & 電子情報通信学会 \\
\hline & 半導体電力変換及びモータドライブ一般 & 岩手 & 9 月 & モータドライブ技術委員会 \\
\hline \multirow{3}{*}{$\begin{array}{l}\text { 産業計測制御 (IIC) } \\
\text { 藤本 康孝(横浜国立大学) } \\
\text { http://www2.ie.or.jp/ diic/ }\end{array}$} & 制御技術のためのエコシステム & 東京 & 3 月 & C部門 制御技術委員会 \\
\hline & 診断·監視技術関連 & 未定 & 6 月 & \\
\hline & 制御技術関連 & 未定 & 8 月 & \\
\hline \multirow{3}{*}{$\begin{array}{l}\text { メカトロニクス制御 (MEC) } \\
\text { 岩崎 誠 (名古屋工業大学) } \\
\text { http://www2.iee.or.jp/ dmec/ }\end{array}$} & 実世界ハプティクス & 未定 & 未定 & \\
\hline & モーションコントロール & 未定 & 未定 & \\
\hline & 精密サーボシステムと制御技術 & 未定 & 未定 & \\
\hline \multirow{2}{*}{$\begin{array}{c}\text { モータドライブ }(\mathrm{MD}) \\
\text { 野ロ 季彦(静岡大学) } \\
\text { http://www2.iee.or.jp/ dmd/ }\end{array}$} & 自動車用など用途指向形モータドライブ & 東京 & 7 月 & $\begin{array}{l}\text { 回転機技術委員会 } \\
\text { 自動車技術委員会 }\end{array}$ \\
\hline & 半導体電力変換およびモータドライブ一般 & 岩手 & 9 月 & 半導体電力変換技術委員会 \\
\hline \multirow{4}{*}{$\begin{array}{c}\text { 回転機 }(\mathrm{RM}) \\
\text { 廣塚 功 }(\text { 中部大学 }) \\
\mathrm{http}: / / \mathrm{www} 2 . \text { iee.or.jp/ drm/ }\end{array}$} & 電磁界数値計算技術とその応用 & 岡山 & 3 月 & B部門 静止器技術委員会 \\
\hline & $\begin{array}{l}\text { 小形モータ一般・永久磁石モータ一般/リニアドライブ一般/家 } \\
\text { 電・民生一般 }\end{array}$ & 未定 & 7 月 & $\begin{array}{l}\text { リニアドライブ技術委員会 } \\
\text { 家電·民生技術委員会 }\end{array}$ \\
\hline & 自動車用など用途指向形モータドライブ & 東京 & 7 月 & $\begin{array}{l}\text { モータドライブ技術委員会 } \\
\text { 自動車技術委員会 }\end{array}$ \\
\hline & 電磁界数值計算技術とその応用 & 未定 & 8 月 & B部門 静止器技術委員会 \\
\hline \multirow{2}{*}{$\begin{array}{c}\text { リニアドライブ }(\mathrm{LD}) \\
\text { 水野 勉 (信州大学) } \\
\mathrm{http}: / / \mathrm{www} 2 . \text { iee.or.jp/ dld/ }\end{array}$} & $\begin{array}{l}\text { 磁気センサ, スマートデバイス, マイクロ磁気デバイス・材料, 小 } \\
\text { 型電源, 高周波磁気デバイス・計測, リニアモータ・アクチュ } \\
\text { エータ, リニアドライブ技術一般, および, 磁気応用一般 }\end{array}$ & 長野 & 6 月 & A部門 マグネテイツクス技術委員会 \\
\hline & $\begin{array}{l}\text { 小形モータ一般·永久磁石モータ一般／リニアドライブ一般／家 } \\
\text { 電民生一般 }\end{array}$ & 大阪 & 8月 & $\begin{array}{l}\text { 回転機技術委員会 } \\
\text { 家電·民生技術委員会 }\end{array}$ \\
\hline \multirow{2}{*}{$\begin{array}{c}\text { 家電·民生 (HCA) } \\
\text { 叶田 玲彦 (日立製作所) } \\
\text { http://www2.iee.or.jp/ dhca/ }\end{array}$} & $\begin{array}{l}\text { スイッチング電源, 家庭向けエネルギー高度利用化技術および } \\
\text { 家電·民生技術一般 }\end{array}$ & 東京 & 5 月 & 電子情報通信学会 \\
\hline & $\begin{array}{l}\text { 小型モータ一般・永久磁石モータ一般/リニアドライブ一般/家 } \\
\text { 電・民生一般 }\end{array}$ & 大阪 & 8 月 & $\begin{array}{l}\text { 回転機技術委員会 } \\
\text { リニアドライブ技術委員会 }\end{array}$ \\
\hline \multirow{2}{*}{$\begin{array}{c}\text { 自動車 }(V T) \\
\text { 貝塚 正明 }(\text { 本田技術研究所) } \\
\text { http://www2.iee.or.jp/ dvt/ }\end{array}$} & 自動車用など用途指向形モータドライブ技術 & 東京 & 7月 & $\begin{array}{l}\text { モータドライブ技術委員会 } \\
\text { 回転機技術委員会 }\end{array}$ \\
\hline & 鉄道や EV/PHV 等のエネルギーストレージ応用システム & 東京 & 9 月 & 交通·電気鉄道技術委員会 \\
\hline
\end{tabular}




\begin{tabular}{|c|c|c|c|c|}
\hline $\begin{array}{l}\text { 技術委員会/委員長 } \\
\text { ホームページアドレス }\end{array}$ & 研究会テーマ & 開催地 & 開催月 & 共催·連催·併催 \\
\hline \multirow{3}{*}{$\begin{array}{c}\operatorname{ITS}(\mathrm{ITS}) \\
\text { 細野 裕行 (日本大学) } \\
\text { http://www2.iee.or.jp/ dits/ }\end{array}$} & 道路交通一般 & 京都 & 3 月 & 電子情報通信学会 \\
\hline & 交通管理・情報提供システム, ITS 一般 & 千葉 & 6 月 & \\
\hline & 道路交通一般 & 東京 & 9 月 & 電子情報通信学会 \\
\hline \multirow{3}{*}{$\begin{array}{c}\text { 交通・電気鉄道 }(\mathrm{TER}) \\
\text { 古関 隆章 (東京大学) } \\
\text { http://www2.iee.or.jp/ dter/ }\end{array}$} & 集電技術, 鉄道一般 & 東京 & 5 月 & \\
\hline & 電気鉄道 & 未定 & 7 月 & \\
\hline & 鉄道や EV/PHV 等のエネルギーストレージ応用システム & 東京 & 9 月 & 自動車技術委員会 \\
\hline \multirow{3}{*}{$\begin{array}{c}\text { ものづくり (MZK) } \\
\text { 南方 英明 (千葉工業大学) } \\
\text { http://www2.iee.or.jp/ / dmzk/ }\end{array}$} & 金属産業応用一般 & 鹿児島 & 3 月 & \\
\hline & 一般産業関連 & 関東 & 6 月 & \\
\hline & 金属産業応用一般 & 地方 & 9 月 & \\
\hline \multirow{2}{*}{$\begin{array}{c}\text { 次世代産業システム(IIS) } \\
\text { 三橋 郁 } \\
\text { (職業能力開発総合大学校) } \\
\text { http://www2.ie.or.jp/ diis/ }\end{array}$} & Okinawa 型ロボット・組み込みサスティナブルシステム & 沖縄 & 3 月 & \\
\hline & 人間社会における環境影響・人間支援・画像処理応用技術 & 東京 & 3 月 & $\mathrm{C}$ 部門 知覚情報研究会 \\
\hline \multirow{2}{*}{$\begin{array}{l}\text { スマートファシリティ(SMF) } \\
\text { 小林 延久 (日立製作所) } \\
\text { http://www2.iee.or.jp/ dsmf/ }\end{array}$} & スマートグリッド/シティ/コミュニティ & 未定 & 6 月 & 電子情報通信学会 \\
\hline & Society5.0 に向けたエネルギーバリューチェーンの最適化 & 未定 & 8 月 & 電子情報技術産業協会 \\
\hline $\begin{array}{c}\text { 公共施設 (PPE) } \\
\text { 松本 信幸(横浜市) } \\
\text { http://www2.iee.or.jp/ dppe/ }\end{array}$ & 未定 & 未定 & 未定 & \\
\hline
\end{tabular}

〈注〉発表申込締切は開催日の 2〜3 ケ月前，研究会資料の原稿締め切りは 1 ケ月前です。

\section{【電気学会論文誌Ｄ３月号特集号「半導体電力変換研究会」案内】}

\section{ゲストエディタ 船渡 寛人 (宇都宮大学)}

平成 31 年 $(2019$ 年) 3 月号では「半導体電力変換研究会」特集号を発行します。半導体電力変換研究会 で取り扱うパワーエレクトロニクス技術は, 産業, 家電, 自動車, 鉄道などの輸送機器, 太陽光発電をはじ めとする分散電源などに広く応用され，電気利用が高度化した現代社会の基盤技術となっています。また， 最近ではワイヤレス電力伝送などの新たな応用も生まれています。

半導体電力変換研究会は, 年 7 回開催されており 160 件以上の発表が行われています。すべての研究会が 他の技術委員会との共催や電子情報通信学会との連催・併催となっており, 基礎的な内容から応用に至るま で幅広い内容の発表が行われる研究会となっています。その中には, 部門誌論文として発表に值する質の高 い発表も数多く含まれていますので, それらの研究会発表を部門誌論文として公表を促すために, 毎年 1 月 の研究会で質疑応答を長めにとる特別セッションを開催しています。

本特集は, 特別セッションで発表された論文を中心として, 半導体電力変換研究会で発表された論文をべ 一スに投稿された論文の内，厳正な査読を経た論文を特集号論文として掲載しています。特別セッションは 毎年行われていましたが，和文誌の特集号は平成 27 年 1 月発行を最後に一時中断しておりましたが，和文 誌の投稿を促進するために平成 30 年から再開されました。最後に, 論文の投稿者, 査読者はじめ特集号に 関係された皆さま方に深くお礼を申し上げます。 


\title{
IEEJ Journal of Industry Applications Vol. 8, No. 2 Special Issue on "IPEC-Niigata 2018"
}

\author{
ゲストエディタ＼cjkstart船渡＼cjkstart寛人（宇都宮大学）
}

IEEJ Journal of Industry Applications（電気学会英文論文誌 D）では，Vol. 8, No. 2 および No. 3 で（論文数 が多ければNo. 4 でも）「Special Issue on “IPEC-Niigata 2018”」を発行します。英文論文誌 D での IPEC 特集 号は IPEC-Hiroshima 特集号（Vol. 4, No. 3）以来 2 度目の企画となります。

IPEC は 1983 年の IPEC-Tokyo 以来今回が 8 回目の開催となります。2010 年の IPEC-Sapporo 以来日中韓 のパワーエレクロニクス関連の国際会議協力の枠組みの中で ECCE-Asia シリーズの一環として開催されて おり, パワーエレクトロニクス関係の国際会議として世界的にも重要な会議の一つとなっております。今回 の IPEC は新潟市朱鷺メッセで 2018 年 5 月に開催され, 1038 名の参加者の下, 673 件の発表が行われまし た。IPECではパワーエレクトロニクスの基本技術である電力変換器のみならず，電気自動車，モータドラ イブ，モーションコントロールなどの応用分野の研究も数多く発表されているため，IPECの論文を一読い ただければパワーエレクトロニクス関連の最新技術動向が明らかになります。

本特集は，IPEC-Niigata 2018 で発表された論文をベースに投稿された論文の内，㛜正な査読を経た論文を 特集号論文として掲載しています。本来No. 3（5 月号）に掲載の予定でしたが，投稿数が多いため前倒し で発行することになりました。特集号を発行するにあたり, 論文の投稿者, 査読者はじめ特集号に関係され た皆さま方に深くお礼を申し上げます。

\section{IEEJ Journal of Industry Applications Vol. 8, No. 2 Special Issue on "Motion Control and its Related Technologies"}

\author{
ゲストエディタ 桂 誠一郎 (慶應義塾大学), 辻 俊明 (埼玉大学)
}

IEEJ Journal of Industry Application（電気学会英文論文誌 D）Vol. 8, No. 2 では特集「Motion Control and its Related Technologies」を企画いたしました。本論文誌ではモーションコントロール分野の特集号を例年企画 しており, 英文論文誌での企画は今年で 4 回目になります。平成 30 年 3 月 4 日〜 6 日に東京電機大学で開催 された電気学会国際ワークショップSAMCON 2018 の発表者から多くの論文を投稿いただきました。これら の投稿論文は厳正な査読プロセスで採否が決定され，16 件が掲載に至りました。採択された論文はいずれも 精密位置決め，力制御，センサ\&アクチュエータ技術等に関する一線級の研究成果をまとめたものであり， モーションコントロール分野の今後を議論するうえで意義の深いものばかりですので是非ともご覧くださ い。

本企画は年々海外からの投稿数も増えつつあり，その国際性が高まっています。今後も企画は継続される 予定であり，次の論文募集は 5 月頭が締切りの予定ですので SAMCON 2019 の発表者はじめ国内外皆々様の ご投稿をお待ち申し上げます。最後に，本特集号を発行するにあたり，ご尽力いただきました投稿者，査読 者，編修委員の皆様に篤く御礼申し上げます。 